PeRRY, T. O. (1976): Maternal effects on the early performance of tree progenies in Tree Physiology and Yield Improvement. Cannell, M. G. R. and Last F. T. (eds). Academic Press. London, England. pp. 473-481.

Pollard, D. F. W. and YING, C. C. (1979): Variance in flushing among and within stands of seedling white spruce. Can. J. For. Res. 9: 517-521.

SARAZIN, S. (2001): Adaptive variation and age-age correlations of Picea glauca from the 194 white spruce series provenances tests at the Petawawa Research Forest in eastern Ontario. B.Sc. (For.) thesis, Lakehead University, Thunder Bay, Ont.
SAS Institute InC. (2000): SAS system for Windows. SAS Institute Inc. Cary, N.C.

TeICH, A. H. and Holst, M. J. (1974): White spruce limestone ecotypes. For. Chron. 50: 110-111.

Teich, A. H., Skeates, D. A. and Morgenstern, E. K. (1975): Performance of white spruce provenances in Ontario. Can. For. Ser. Ont. Min Nat. Resources Special Joint Rep. No.1. $31 \mathrm{p}$.

\title{
Genetic Variability and Early Growth Performance of Eucalyptus tereticornis Sm. in Provenance cum Progeny Trials in India
}

\author{
By H. S. GinwaL", Pradip Kumar, V. K. Sharma, A. K. Mandal and C. E. Harwood ${ }^{1}$ \\ Division of Genetics and Tree Propagation, Forest Research Institute, P.O. I.P.E. Kaulagarh Road, \\ Dehradun 248195 (Uttaranchal) India \\ (Received $8^{\text {th }}$ November 2004)
}

\begin{abstract}
Results of provenance cum progeny trials of Eucalyptus tereticornis Sm. laid out in 2002 at three sites viz. FRI Campus (Uttaranchal), Chiryanpur (Uttaranchal) and Midnapore (West Bengal) located in tropical region of India are reported and discussed. Thirteen provenances representing 91 families from Australia and Papua New Guinea (PNG) viz. Oro bay to Emo, PNG; Sirinumu Sogeri Plat, PNG; Warwick, QLD; Yurammie, SF, NSW; Buckenbowra SF, NSW; Selection flat SF559, NSW; Credition SF, QLD; Cardwell, QLD; Mitchell River MT Molloy, QLD; Mill stream archer creek, QLD; Helenvale, QLD; Walsh River, QLD; Burdekin River, QLD were evaluated from nursery stage to field performance (age 21 months). As a local seed source open-pollinated seeds collected from selected interspecific Eucalyptus F1 hybrid trees of FRI-4, FRI-5 and Mysore gum (Eucalyptus teretirornis) were used to serve as check material (control). Significant differences between the provenances and families at age 21 months were observed for height, clean stem length, collar diameter and field survival. Significant provenance $\mathrm{x}$ site interaction was observed for height. In general the north Queensland provenances performed better and in particular two provenances viz. Walsh River, QLD and Burdekin River, QLD ranked the best in comparison to others at this age. Results indicate that significant genetic differences exist between the families and provenances of $E$. tereticornis. The growth traits were inter-correlated with each other. Geographic clinal variation pattern was observed in some of the growth traits viz. height, clean stem height and collar diameter. There were fair differences between phenotypic and genotypic coefficient of variability. Heritability (narrow sense) values were fairly good for height and clear stem length in comparison to collar diameter. The relative performance of the provenances was fairly consistent throughout test sites.
\end{abstract}

1) CSIRO Forestry and Forest Products, Private Bay 12, Hobart, Australia 7001

*) Author for correspondence (e-mail: ginwalhs@icfre.org; ginwalhs@ rediffmail.com
Key words: Eucalyptus tereticornis, variation, provenance, genetic improvement, productivity, heritability, progeny, provenance $\mathrm{x}$ site interaction.

\section{Introduction}

Eucalyptus tereticornis Sm. commonly known as forest red gum is native to Papua New Guinea and Victoria, New South Wales and Queensland of Australia. It has a very extensive natural distribution in a long narrow strip from southern Papua New Guinea to Victoria, Australia (ElDRIDGe et al., 1994), thus facing wide climatic variation of dry summer and winter seasons. The altitudinal range of its occurrence varies from sea level to about $1000 \mathrm{~m}$ with remarkable variation in annual rainfall from 500-1500 mm (ELDRIDGE et al., 1994). Hence populations of eucalyptus both natural and planted contain considerable amount of genetic variation. This species has been introduced for production of wood for fuel, poles, construction and pulp in many parts of the world and ranks among the most extensively planted Eucalyptus in the tropics and subtropics (ZoBel et al., 1987; EvANs, 1992). It's popularity, as that of other widely planted eucalypts is attributed to its rapid growth and production of desirable wood when grown in a wide range of environmental and soil conditions (ZoBEL et al., 1987; LAMPRECHT, 1989).

Populations of Eucalyptus in India are highly inbred and the existing variability of Eucalyptus has been over exploited through intensive selection of promising trees and their multiplication for commercial plantation. The Eucalyptus hybrid also known as "Mysore gum" represents about half of the eucalypts planted in many parts of India (JACOBS, 1981), which is believed to be derived from one small stand of the early introductions in Nandi Hills (PRYOR, 1966; ChatURVEDI, 1976). Lack of sufficient genetic variability is one of the important reason for low productivity of Eucalyptus plantations in India as compared to other countries because this restricts the intensity of selection in insufficient base population. In order to broaden 
the genetic base of Eucalyptus in India, and/or to create/introduce more variability for further selection and improvement, it is necessary to introduce and evaluate populations of wide geographical distribution. Australia and Papua New Guinea being the native place of Eucalyptus is the best choice for testing their populations in Indian conditions. With this background, Australian populations of $E$. tereticornis are being evaluated in a numbers of trials in different eco-climatic zones of India with the objective of identification of seed sources/families/individuals, which are more productive in terms of wood volume and biomass production. The superior seed sources could be used under afforestation programme or outstanding individuals could be clonally multiplied on mass scale. If such plant material is introduced in the forestry sector a very high magnitude of genetic gain could be achieved in terms of yield of wood per unit area per unit time.

Exploration of naturally existing variability offers scope to tree breeder for making rapid genetic advance at relatively low cost in terms of energy and finance. The form and growth of $E$. tereticornis varies considerably according to provenances (MARTIN, 1978). Considerable seed source and provenance differences have been noticed in growth rates and stem form in many recent trials in Bangladesh, Brazil, Papua New Guinea and Uganda (ELDRIDGE et al., 1994). A number of provenance trials of E. tereticornis have been established in many countries, and the performance of the provenances has been producing significant results. The results so far obtained indicate a significant outfit performance of north Queensland provenances particularly Kennedy River in India (CHATURVEDI et al., 1989) and China (ZHou and BAI, 1989), Laura and Cooktown provenance performed better in Brazil (TiMONI et al., 1983), Mount Garnet and Laura, in Bangladesh (DAvidSON and DAS, $1985)$ etc. Hence it is important to test more seed sources from north Queensland and near by areas as a continuing effort to find appropriate provenances for particular sites (ELDRIDGE $e t$ al., 1994).

In the present communication results of growth pattern and genetic analysis of families of E. tereticornis representing 13 sources of Australia and Papua New Guinea origin, established in the form of provenance cum progeny trial at three different locations of India, are presented.

\section{Material and Methods}

The study was conducted at three sites. Two sites, site I and site III fall in northern part of India namely the Forest Research Institute (FRI) campus, Dehradun, Uttaranchal $\left(30^{\circ}\right.$ $\mathrm{N}$ Lat., $76^{\circ} \mathrm{E}$ Long, $610 \mathrm{~m}$ altitude), Chiryanpur, Uttaranchal $\left(29^{\circ} \mathrm{N}\right.$ Lat., $78^{\circ} \mathrm{E}$ long., $460 \mathrm{~m}$ altitude) respectively and site II i.e. Midnapore, West Bengal ( $22^{\circ} \mathrm{N}$ Lat., $87^{\circ} \mathrm{E}$ long., $23 \mathrm{~m}$ altitude) in eastern India. The information on soil and site characteristics of the experimental area is given in Table 2 .

Open-pollinated seeds of 91 seedlots (families) of E. tereticornis belonging to 13 provenances of Papua New Guinea and Australian origin were obtained from Australian Seed Centre, CSIRO Australia. As control open pollinated seeds collected from controlled hybrid FRI-4 (E. tereticornis x $E$. camaldulensis) and natural hybrid FRI-5 (E. camaldulensis $\mathrm{x} E$. tereticornis), and Mysore gum (E. tereticornis) were used. The detail of seed sources and their geographical locations is given in Table 1. Seeds were sown directly in earthen pots containing potting mixture of sand, soil and farm yard manure in the ratio of 1:1:1 (by volume). Prior to sowing the potting mixture was treated with $0.2 \%$ 'Bavistein' a fungicide to avoid any chance of fungus infection to newly germinated seedlings. Pots were irrigated with fine sprayer to keep them wet and maintained in glass house. Young two leaved seedlings were pricked out in root trainers $(200 \mathrm{cc})$ containing potting mixture of sand, soil and compost (1:1:3, by volume). Seedlings in root trainers were arranged in the nursery in a randomized block design and maintained there till they attained the plantable height.

Table 1. - Provenance detail of Eucalyptus tereticornis and their geographical locations.

\begin{tabular}{|c|c|c|c|c|c|c|}
\hline \multirow[t]{2}{*}{ Index } & \multirow{2}{*}{$\begin{array}{l}\text { Provenance/ Seed } \\
\text { lot No. }\end{array}$} & \multirow{2}{*}{$\begin{array}{l}\text { Number } \\
\text { of } \\
\text { families }\end{array}$} & \multicolumn{4}{|c|}{ Origin } \\
\hline & & & Locality & Lat. & Long. & $\begin{array}{l}\text { Altitude } \\
\text { (m) }\end{array}$ \\
\hline$\$ 1$ & 13399 & 6 & $\begin{array}{l}\text { Oro Bay to Emo, } \\
\text { PNG }\end{array}$ & 0857 & 14828 & 200 \\
\hline S2 & 13418 & 1 & $\begin{array}{l}\text { Sirinumu Sogeri } \\
\text { Plat, PNG }\end{array}$ & 0930 & 14726 & 580 \\
\hline$\$ 3$ & 17762 & 4 & Warwick, QLD & 2815 & 15205 & 450 \\
\hline$\$ 4$ & 17768 & 5 & $\begin{array}{l}\text { Yurammie, SF, } \\
\text { NSW }\end{array}$ & 3649 & 14945 & 170 \\
\hline S5 & 17770 & 4 & $\begin{array}{l}\text { Buckenbowra SF, } \\
\text { NSW }\end{array}$ & 3540 & 15007 & 110 \\
\hline$\$ 6$ & 18732 & 10 & $\begin{array}{l}\text { Selection Flat } \\
\text { SF559, NSW }\end{array}$ & $29 \quad 10$ & 15258 & 40 \\
\hline$\$ 7$ & 19315 & 11 & $\begin{array}{l}\text { Credition SF, } \\
\text { QLD }\end{array}$ & 217 & $148 \quad 31$ & 730 \\
\hline$\$ 8$ & 20468 & 9 & Cardwell, QLD & $18 \quad 10$ & 14558 & 84 \\
\hline$\$ 9$ & 20469 & 5 & $\begin{array}{l}\text { Mitchell River } \\
\text { MT Molloy, } \\
\text { QLD }\end{array}$ & 1644 & 14520 & 390 \\
\hline$\$ 10$ & 20470 & 9 & $\begin{array}{l}\text { Mill Siream } \\
\text { Archer creek, } \\
\text { QLD }\end{array}$ & 1739 & 14521 & 670 \\
\hline S11 & 20471 & 9 & Helenvale, QLD & 1548 & 14515 & 325 \\
\hline S12 & 20472 & 7 & $\begin{array}{l}\text { Walsh River, } \\
\text { QLD }\end{array}$ & 1720 & 14518 & 762 \\
\hline$\$ 13$ & 20474 & 11 & $\begin{array}{l}\text { Burdekin River, } \\
\text { QLD }\end{array}$ & 1948 & 14604 & 291 \\
\hline$\$ 14$ & $\begin{array}{l}\text { Lucal (seed } \\
\text { collected from trees } \\
\text { of FRI-4, FRL-5 and } \\
\text { Mysore gum ) }\end{array}$ & 3 & 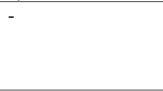 & 3030 & $76 \quad 04$ & 640 \\
\hline
\end{tabular}

Three-month-old seedlings were planted in the field (pit size $45 \times 45 \times 45 \mathrm{~cm}$ ) at the espacement of $2 \times 2 \mathrm{~m}$ in August 2002 in a randomized complete block design at three sites viz. FRI campus ( 4 tree plot with 8 replications), Midnapore ( 4 tree plot with 9 replications) and Chiryanpur (5 tree plot with 9 replications). Each family constituted a plot with 4 or 5 tree line plot ( 5 tree line plot at Chiryanpur). All the trees in each plot constituted the measuring unit in all the replications. Identity of both, provenances as well as that of mother trees was maintained in the experimental design. The first assessment was carried out at age 6 months after planting and subsequently after 12 months and 18 months. In this paper results of 21 months growth (3 month in nursery +18 months in field) of $E$. tereticornis provenances have been described. The traits assessed were plant height $(\mathrm{m})$, clean stem height $(\mathrm{m})$ (length from ground to first branch of plant), collar diameter $(\mathrm{cm})$, and survival percentage. No fertilizer was applied to these trials. Cleaning operations for removal of weeds etc. in all the three experimental trials were done once in a year just after the rainy season.

The data were analyzed for each site, to determine the provenance effect and family effect separately through two-way analysis of variance (ANOVA) and further for Least Significance Difference test using computer software GENSTAT 5.0 (release 3.2, 1995 second addition, Lawes Agricultural Trust, IACR, Roathmsted). The correlations were estimated using the SPSS (version 6.1) computer program (SPSS Inc. 233 S. Wacker Drive, $11^{\text {th }}$ floor, Chicago, IL 60606-6307). Variance components and heritability (narrow sense) were estimated following Williams et al. (2002) method using GENSTAT 5.0. A coefficient of relationship (r) $1 / 2.5$ was used for the calculation of heritability, as recommended by WILLIAMs et al. (2002) for open-pollinated eucalypt populations. The genotype $\mathrm{x}$ environ- 
Table 2. - Site and soil characteristics of the experimental sites.

\begin{tabular}{|c|c|c|c|}
\hline Site and soil characteristics & FRI Campus & Midnapore & Chiryanpur \\
\hline Mean annual rainfall $(\mathrm{mm})$ & 2160 & 1445 & 1166 \\
\hline $\begin{array}{c}\text { Mean annual temperature ("C) } \\
\text { Maximum } \\
\text { Minimum }\end{array}$ & \begin{tabular}{|l|}
35 \\
13.3
\end{tabular} & $\begin{array}{l}35.2 \\
18.5\end{array}$ & $\begin{array}{l}36.0 \\
15.0\end{array}$ \\
\hline Soil texture & Clay loam & Lateritic & Clay loam \\
\hline Soil pH & 6.3 & 5.9 & 6.6 \\
\hline Water holding capacity (\%) & 36.61 & 35.4 & 38 \\
\hline Drainage & $\begin{array}{l}\text { Well drained, no } \\
\text { water stagnation }\end{array}$ & $\begin{array}{l}\text { Moderately } \\
\text { drained, no water } \\
\text { stagnation }\end{array}$ & $\begin{array}{l}\text { Moderately well } \\
\text { drained, however } \\
\text { stagnation of water } \\
\text { observed during heavy } \\
\text { rains }\end{array}$ \\
\hline Growth conditions at the site & Very good & \begin{tabular}{|l} 
Very good \\
\end{tabular} & Average \\
\hline Biotic interference & Very Low & Very Low & Very high \\
\hline Remarks & $\begin{array}{l}\text { Area is within the } \\
\text { boundary of the } \\
\text { experimental area. }\end{array}$ & $\begin{array}{l}\text { Area is within the } \\
\text { boundary of the } \\
\text { experimental area. }\end{array}$ & $\begin{array}{l}\text { Area lies in open forest } \\
\text { having high incidence } \\
\text { of wild and domestic } \\
\text { animals and is covered } \\
\text { with dense weed, } \\
\text { which grow rapidly } \\
\text { even after cleaning. }\end{array}$ \\
\hline
\end{tabular}

ment interaction ( $\mathrm{G} \times \mathrm{E}$ ) was calculated as per the method described by WilliaMs et al. (2002) by taking into account the observations of all the three sites. One provenance (S2), which was not planted at all the three sites, was not included in the analysis.

\section{Results}

Data on one and half year field growth in respect of morphological traits viz. height, clean stem height, collar diameter and survival percentage pertaining to 94 families of $E$. tereticornis belonging to 13 geographical locations of Australia and one of India at three sites are presented in Table 3.

\section{Site I (FRI campus)}

Highly significant differences $(\mathrm{P}<0.001)$ were observed between the provenances and between the families (irrespective of provenance) for height, clean stem length, collar diameter and survival percentage. The provenance S13 attained a maximum height, followed by $\mathrm{S} 5, \mathrm{~S} 12, \mathrm{~S} 6$ and $\mathrm{S} 10$. These provenances performed better than the local (control) seed source. Maximum clean stem length was recorded in S6 followed by S13 and S12. Collar diameter was maximum in S5 closely followed by S12, and S11. Field survival was recorded maximum in S5, which was closely followed by S11 and S9. The range of variation at family level irrespective of provenances was large in respect of height, clean stem height, collar diameter and survival per cent (Table 3) as evidenced from the values of coefficient of variation. Over all the performance of S13, S12 and S5 provenances was better than others.

\section{Site II (Midnapore)}

The provenance and families varied significantly $(\mathrm{P}<0.001)$ at Midnapore site for height, clean stem height, collar diameter and field survival. The range of family variation (irrespective of provenance) was large in all the growth traits. Maximum height was recorded in S12 provenance. The provenance S13, S10, S6, S3, S11 and S9 performed slightly better than the local source (control). The clean stem height and collar diameter also followed almost a similar trend as with the height. The field survival at age one and half year, was found maximum in S9 provenance which was closely followed by S13. Seven provenances (S9, S13, S12, S8, S3, S10, S11) recorded more than $90 \%$ field survival. Except S1, S4 and S6, all the other provenances gave higher survival than the local source. A considerable amount of variability was observed between the provenances for the growth traits as evidenced by CV (\%). Two provenances i.e. S12 and S13 maintained their superiority in majority of the growth traits studied. Performance of provenance S11, S9 and S6 was also fairly good.

\section{Site III (Chiryanpur)}

Significant differences $(\mathrm{P}<0.001)$ were detected among provenances in height, clean stem height, collar diameter and survival per cent. Also there was significant variation between

Table 3. - Growth performance of various provenances of Eucalyptus tereticornis at three sites.

\begin{tabular}{|c|c|c|c|c|c|c|c|c|c|c|c|c|}
\hline \multirow{2}{*}{$\begin{array}{l}\text { Provenance } \\
\text { Index No. }\end{array}$} & \multicolumn{4}{|c|}{ FRI campus } & \multicolumn{4}{|c|}{ Midnapore } & \multicolumn{4}{|c|}{ Chiryanpur } \\
\hline & $\begin{array}{l}\text { Height } \\
(\mathrm{m})\end{array}$ & $\begin{array}{l}\text { Clean stem } \\
\text { height }(\mathrm{m})\end{array}$ & $\begin{array}{l}\text { Collar dia. } \\
(\mathrm{mm})\end{array}$ & $\begin{array}{l}\text { Survival } \\
(\%)\end{array}$ & Height $(\mathrm{m})$ & $\begin{array}{c}\text { Clean stem } \\
\text { height }(m)\end{array}$ & $\begin{array}{c}\text { Collar dia. } \\
(\mathrm{cm})\end{array}$ & $\begin{array}{l}\text { Survival } \\
(\%)\end{array}$ & $\begin{array}{l}\text { Height } \\
\text { (m) }\end{array}$ & $\begin{array}{l}\text { Clean stem } \\
\text { height }(\mathrm{m})\end{array}$ & $\begin{array}{c}\text { Collar dia. } \\
(\mathrm{mm})\end{array}$ & $\begin{array}{l}\text { Survival } \\
(\%)\end{array}$ \\
\hline S1 & 1.63 & 0.41 & 16.39 & 72.92 & 2.55 & 1.51 & 1.45 & 77.78 & 0.87 & 0.36 & 7.52 & 50.00 \\
\hline S2 & 1.68 & 0.38 & 15.96 & 87.50 & . & . & 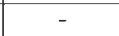 & - & . & - & - & - \\
\hline S3 & 1.94 & 0.49 & 19.22 & 80.47 & 2.66 & 1.67 & 1.61 & 90.74 & 0.92 & 0.32 & 7.78 & 62.22 \\
\hline S4 & 2.04 & 0.41 & 21.72 & 81.25 & 2.15 & 1.42 & 1.34 & 72.22 & 0.88 & 0.28 & 8.61 & 61.33 \\
\hline S5 & 2.29 & 0.47 & 24.72 & 89.84 & 2.39 & 1.52 & 1.59 & 88.89 & 0.93 & 0.33 & 8.51 & 61.11 \\
\hline S6 & 2.12 & 0.60 & 19.67 & 78.12 & 2.77 & 1.73 & 1.74 & 86.11 & 0.83 & 0.35 & 7.80 & 49.78 \\
\hline S7 & 1.93 & 0.47 & 20.50 & 85.51 & 2.42 & 1.57 & 1.48 & 89.81 & 0.77 & 0.29 & 7.53 & 51.11 \\
\hline 58 & 1.85 & 0.45 & 19.66 & 74.31 & 2.38 & 1.53 & 1.51 & 92.46 & 0.85 & 0.27 & 7.64 & 44.44 \\
\hline 59 & 1.89 & 0.41 & 20.44 & 88.12 & 2.65 & 1.62 & 1.68 & 97.78 & 0.87 & 0.33 & 8.41 & 59.56 \\
\hline $\mathrm{S} 10$ & 2.15 & 0.47 & 22.28 & 86.11 & 2.78 & 1.70 & 1.78 & 90.01 & 0.84 & 0.31 & 8.11 & 59.26 \\
\hline S11 & 2.04 & 0.45 & 22.70 & 88.89 & 2.67 & 1.64 & 1.77 & 91.67 & 0.85 & 0.32 & 8.18 & 52.78 \\
\hline $\mathrm{S} 12$ & 2.24 & 0.52 & 23.29 & 83.48 & 3.17 & 1.81 & 2.10 & 94.44 & 1.05 & 0.35 & 8.98 & 64.44 \\
\hline S13 & 2.35 & 0.56 & 22.49 & 86.65 & 2.99 & 1.77 & 1.88 & 97.22 & 0.98 & 0.40 & 8.24 & 66.67 \\
\hline S14 & 2.08 & 0.45 & 21.87 & 86.46 & 2.57 & 1.65 & 1.63 & 88.89 & 0.85 & 0.34 & 7.63 & 44.44 \\
\hline Family Range & $1.47-3.00$ & $0.30-0.73$ & $15.08-28.26$ & $40.63-96.88$ & $1.05-4.85$ & $0.30-2.73$ & $0.60-1.71$ & $63.89-100$ & $0.25-6.50$ & $0.05-1.25$ & $1.50-35.00$ & $\begin{array}{l}33.33- \\
84.44 \\
\end{array}$ \\
\hline $\mathrm{CV}(\%)$ & 20.17 & 29.48 & 25.48 & 23.86 & 15.50 & 13.45 & 22.70 & 17.34 & 38.48 & 53.26 & 36.26 & 47.02 \\
\hline $\begin{array}{r}\text { F test : Provenance } \\
\text { Family } \\
\end{array}$ & $\begin{array}{l}* \star * \\
* * *\end{array}$ & $\begin{array}{ll}* \star * \\
* \star *\end{array}$ & $\begin{array}{l}* \star * \\
* *\end{array}$ & $\begin{array}{ll}* \star \star \\
\star \star \star *\end{array}$ & $\begin{array}{l}* \star \star \\
\star \star \star \\
* \star\end{array}$ & $\begin{array}{l}* \star * * \\
* \star * *\end{array}$ & $\begin{array}{l}* * * \\
\star \star * \\
\end{array}$ & $\begin{array}{c}* \star \star \\
*\end{array}$ & $\begin{array}{l}* \star \star \\
\star \star \star \\
* \star\end{array}$ & $\begin{array}{ll}* \star \star \\
* \star \star \\
* \star 1\end{array}$ & $\begin{array}{l}* \star \star \\
\star \star\end{array}$ & $\begin{array}{l}\star \star \star \star \\
\star \star \star \star\end{array}$ \\
\hline $\begin{array}{c}\text { LSD : Provenance } \\
\text { Family }\end{array}$ & $\begin{array}{l}0.300 \\
0.408\end{array}$ & $\begin{array}{l}0.104 \\
0.139\end{array}$ & $\begin{array}{l}3.928 \\
5.322\end{array}$ & $\begin{array}{l}14.368 \\
19.457\end{array}$ & $\begin{array}{l}0.287 \\
0.387\end{array}$ & $\begin{array}{l}0.135 \\
0.206\end{array}$ & $\begin{array}{l}0.267 \\
0.361\end{array}$ & $\begin{array}{l}10.878 \\
14.669\end{array}$ & $\begin{array}{l}0.143 \\
1.491\end{array}$ & $\begin{array}{l}0.075 \\
0.163\end{array}$ & $\begin{array}{l}1.247 \\
3.413\end{array}$ & $\begin{array}{l}11.240 \\
24.407\end{array}$ \\
\hline $\begin{array}{c}\text { S.E. } \pm: \text { Provenance } \\
\text { Family }\end{array}$ & $\begin{array}{l}0.153 \\
0.208\end{array}$ & $\begin{array}{l}0.053 \\
0.071\end{array}$ & $\begin{array}{l}2.00 \\
2.71\end{array}$ & $\begin{array}{l}7.316 \\
9.907\end{array}$ & $\begin{array}{l}0.146 \\
0.197\end{array}$ & $\begin{array}{l}0.078 \\
0.105\end{array}$ & $\begin{array}{l}0.136 \\
0.184\end{array}$ & $\begin{array}{l}5.539 \\
7.469\end{array}$ & $\begin{array}{l}0.073 \\
0.759\end{array}$ & $\begin{array}{l}0.038 \\
0.083\end{array}$ & $\begin{array}{l}0.635 \\
1.738\end{array}$ & $\begin{array}{c}5.726 \\
12.434\end{array}$ \\
\hline
\end{tabular}

Significance level: $* \mathrm{P}<0.05$, ** $\mathrm{P}<0.01$, *** $\mathrm{P}<0.001, \mathrm{NS}-$ Non significant. 
the families (irrespective of the provenances). Height growth was recorded maximum in $\mathrm{S} 12$ provenance, however it was at par with S13, S5 and S3. Except S10 and S7, all provenances registered more height than the local seed source (S14). The S13 provenance had maximum clean stem height, though it was at par with S12, S6 and S14. Only three provenances (S13, $\mathrm{S} 12, \mathrm{~S} 6)$ exceeded the control (local source) in respect of clean stem height. Maximum collar diameter was attained by S12 provenance, which was at par with $\mathrm{S} 13, \mathrm{~S} 9, \mathrm{~S} 4, \mathrm{~S} 5, \mathrm{~S} 10$ and $\mathrm{S} 12$. Field survival was recorded maximum in S13 provenance, however it was statistically at par with the S12, S3, S4 and S5. Local seed source showed the minimum survival. Based upon the values of $\mathrm{CV}$ and range of the family means, a wide range of variability was observed in respect of the growth traits.

\section{Variation patterns}

Coefficient of variation (CV) for the characters that showed significant differences between the provenances and between the families, are presented in Table 3. It is apparent that all provenances laid out at the three sites did not show same magnitude of variation for a given characters. For example at Chiryanpur, maximum variation was observed across the provenances for most of the characters studied while at site Midnapore it was the minimum. Also, all of the traits did not exhibit the same amount of variation under the similar site condition.

\section{Provenance $x$ site interaction}

Analysis of variance across the sites revealed significant provenance $\mathrm{x}$ site interactions under this study (Table 4). The provenance $\mathrm{x}$ site interaction was highly significant for height but it was found non-significant for clean stem height, collar diameter and survival per cent. The pooled, across site means of the provenances showed a significant difference between provenances for all the characters except survival and revealed that the ranking of the provenances did not vary much with the site. Among the different provenances the performance of the S12 and S13 provenance was found significantly superior

Table 4. - Growth performance (pooled) of various seed sources of Eucalyptus tereticornis across different sites.

\begin{tabular}{|c|c|c|c|c|}
\hline $\begin{array}{l}\text { Provenance } \\
\text { Index No. }\end{array}$ & Height (m) & $\begin{array}{l}\text { Clean stem } \\
\text { height }(\mathrm{m})\end{array}$ & $\begin{array}{l}\text { Collar } \\
\text { diameter } \\
(\mathrm{mm})\end{array}$ & Survival (\%) \\
\hline S1 & 1.683 & 0.76 & 12.80 & 66.90 \\
\hline S2 & - & - & - & - \\
\hline S3 & 1.840 & 0.83 & 14.37 & 77.81 \\
\hline S4 & 1.690 & 0.70 & 14.58 & 71.60 \\
\hline S5 & 1.870 & 0.77 & 16.38 & 79.95 \\
\hline S6 & 1.907 & 0.89 & 14.96 & 71.34 \\
\hline S7 & 1.707 & 0.78 & 14.28 & 75.48 \\
\hline S8 & 1.693 & 0.75 & 14.13 & 70.40 \\
\hline S9 & 1.803 & 0.79 & 15.22 & 81.82 \\
\hline$S 10$ & 1.923 & 0.83 & 16.06 & 78.46 \\
\hline S11 & 1.853 & 0.80 & 16.19 & 77.78 \\
\hline $\mathrm{S} 12$ & 2.153 & 0.89 & 17.76 & 80.79 \\
\hline S13 & 2.107 & 0.91 & 16.51 & 83.51 \\
\hline S14 & 1.833 & 0.81 & 15.27 & 73.26 \\
\hline F test $\begin{array}{r}\text { Provenance } \\
\text { Provenance } x \text { site }\end{array}$ & $\begin{array}{l}\star \star \star \\
\star \star \star\end{array}$ & $\begin{array}{l}* \star \star \\
\text { NS }\end{array}$ & $\begin{array}{l}\star \star \star \\
\text { NS }\end{array}$ & $\begin{array}{l}\text { NS } \\
\text { NS }\end{array}$ \\
\hline
\end{tabular}

Significance level: *** $\mathrm{P}<0.001, \mathrm{NS}-$ Non significant.
Table 5. - Correlation coefficient (r) among the studied traits and between the geographical geographical coordinates of Eucalyptus tereticornis provenances.

\begin{tabular}{|c|c|c|c|c|c|}
\hline \multirow[t]{2}{*}{ Genetic parameters } & \multicolumn{3}{|c|}{ Growth parameters } & \multicolumn{2}{|c|}{ Geographical coordinates } \\
\hline & Ileight & $\begin{array}{c}\begin{array}{c}\text { Clear stem } \\
\text { height }\end{array} \\
\end{array}$ & $\begin{array}{c}\text { Collar } \\
\text { diameter }\end{array}$ & Latitude & Altitude \\
\hline \multicolumn{6}{|l|}{ FRI campus } \\
\hline Height & 1.000 & & & $256^{*}$ & .035 \\
\hline Clean stem height & $.699^{\star \star}$ & 1.000 & & $212^{*}$ & -.126 \\
\hline Collar diameter & $.835^{* *}$ & $.396^{\star \star *}$ & 1.000 & .177 & .141 \\
\hline \multicolumn{6}{|l|}{ Midnapore } \\
\hline Height & 1.000 & & & $-.267^{\star}$ & .192 \\
\hline Clean stem height & $.914^{\star \star}$ & 1.000 & & -.202 & .142 \\
\hline Collar diameter & $.919^{\star *}$ & $.808^{* *}$ & 1.000 & $-.249^{*}$ & .178 \\
\hline \multicolumn{6}{|l|}{ Chiryanpore } \\
\hline Height & 1.000 & & & -.073 & .059 \\
\hline Clean stem height & $.730^{\star \star}$ & 1.000 & & -.151 & -.070 \\
\hline Collar diameter & $.783^{\star \star}$ & $.586^{\star \star}$ & 1.000 & -.023 & .056 \\
\hline
\end{tabular}

** Correlation is significant at the 0.01 level.

* Correlation is significant at the 0.05 level.

than others in respect of the pooled values for growth traits. The performance of the local seed source was not found encouraging when compared with the best performers.

\section{Correlations}

The correlation coefficient (r) among the growth traits at three different sites are presented in Table 5. Height, clean stem height and collar diameter were found to have higher significant positive relationship with each other, across the sites. In order to find out the relationship of the growth traits with the geographic location of the provenances particularly latitude and altitude, simple correlations were estimated between these geographical coordinates and the growth traits in each site (Table 5). Since E. tereticornis is found in the form of a narrow long strip along the east coast, the correlations with longitude was not of much significance, hence it was not established. Correlation with latitude is more meaningful and was found significantly and positively correlated with height and clean stem height at FRI campus, however a negative correlation was observed with height and collar diameter at Midnapore, while at Chiryanpur, no correlation with latitude could be observed. Altitude did not reveal any significant relationship with the growth traits.

\section{Genetic analysis}

Variance components and individual heritabilities for growth traits at each test site are presented in Table 6. Fair differences were observed between the values of genotypic and phenotypic variance and genotypic and phenotypic co-efficient of variation for all the characters. Estimates of individual heritabilities for growth traits were moderate and ranged from 0.047 to 0.290 . The heritability values were poor for collar diameter and number of branches at FRI and Chiryanpur. The heritability for height was quite good and ranged between 0.117 and 0.290 across the sites. The values of heritability changed with the sites with the same set of genotypes. In general the heritability values were poor in the trial of Chiryanpur site.

\section{Discussion}

The results of this study show that the provenances and families in most of the cases were significantly different in growth 
Table 6. - Estimates of genetic variables determined from measurements of various studied traits.

\begin{tabular}{|l|c|c|c|c|c|c|c|c|c|}
\hline \multicolumn{1}{|c|}{ Genetic parameters } & \multicolumn{3}{|c|}{ FRI campus } & \multicolumn{3}{c|}{ Midnapore } & \multicolumn{3}{c|}{ Chiryanpur } \\
\cline { 2 - 11 } & Height & $\begin{array}{c}\text { Clean } \\
\text { stem } \\
\text { height }\end{array}$ & $\begin{array}{c}\text { Collar } \\
\text { diameter }\end{array}$ & Height & $\begin{array}{c}\text { Clean } \\
\text { stem } \\
\text { height } \\
1.657\end{array}$ & $\begin{array}{c}\text { Collar } \\
\text { diameter }\end{array}$ & Height & $\begin{array}{c}\text { Clean } \\
\text { stem } \\
\text { height }\end{array}$ & $\begin{array}{c}\text { Collar } \\
\text { diameter }\end{array}$ \\
\hline Mean & 6.826 & 1.616 & 21.070 & 2.695 & 1.715 & 0.882 & 0.329 & 8.06 \\
\hline Plot level variance & 0.796 & 0.047 & 11.886 & 0.056 & 0.015 & 0.054 & 0.064 & 0.003 & 2.953 \\
\hline Tree level variance & 3.404 & 0.594 & 52.726 & 0.411 & 0.105 & 0.341 & 0.118 & 0.066 & 13.084 \\
\hline Family variance & 0.313 & 0.028 & 1.783 & 0.061 & 0.007 & 0.030 & 0.008 & 0.003 & 0.305 \\
\hline Phenotypic variance & 4.513 & 0.669 & 66.395 & 0.235 & 0.008 & 0.182 & 0.124 & 0.034 & 8.89 \\
\hline Additive genetic variance & 0.782 & 0.070 & 4.457 & 0.061 & 0.057 & 0.030 & 0.009 & 0.004 & 0.354 \\
\hline Heritability (narrow sense) & 0.173 & 0.117 & 0.067 & 0.290 & 0.147 & 0.177 & 0.108 & 0.117 & 0.047 \\
\hline $\begin{array}{l}\text { Genotypic coefficient of variance } \\
\text { Phenotypic coefficient of }\end{array}$ & 12.95 & 16.37 & 10.02 & 9.16 & 5.29 & 10.09 & 10.87 & 18.20 & 7.38 \\
\hline variance & 31.12 & 50.61 & 38.67 & 17.98 & 14.41 & 24.87 & 39.91 & 56.04 & 36.99 \\
\hline
\end{tabular}

The coefficient of relationship for the families is taken 0.4 for the analysis.

variables and have showed a considerable amount of genetic variability indicating a scope of genetic improvement in the material in hand. The growth data of individual sites and the pooled growth data of three sites clearly indicate that the north Queensland provenances are good performers. The two provenances in particular i.e. Walsh River and Burdekin river, Queensland maintained their superiority throughout the test sites. The superiority of provenance from the northern parts of Australia when planted in tropical exotic environment compared to those from the southern parts of the country has been reported earlier in trials of $E$. tereticornis and E. camaldulensis trials (OTEGBeye, 1985; Chapola and NGulube, 1991; KAARAKKA and JoHANsson, 1993). This has been attributed to climatic differences between the two groups, the northern parts having a predominantly summer rainfall as the tropical exotic environments while the southern parts have a winter rainfall pattern (Chamshama et al., 1999).

Overall the growth performance of the provenances was best at Midnapore site, than FRI and was poor at Chiryanpur. At Chiryanpur the growth of plants were affected by heavy growth of weeds causing suppression and competition for nutrition, damage of plant by domestic as well as wild animals and water stagnation during heavy rains. These factors might have led to slow growth of the plants at this site. Although weeds were cleaned immediately after the rainy season (July-September) weeding did not prove very effective. Such conditions did not prevail at the other two sites. The best performance in growth at Midnapore could be attributed the high mean annual temperature of this site as compared to the other two sites and also the ground water table is high in this area $(4$ to $8 \mathrm{~m})$ in comparison to other sites. Temperature in Midnapore normally does not fall below $6^{\circ} \mathrm{C}$ throughout the year. However, the other two sites viz. FRI and Chiryanpur experience the minimum temperature in the range of $0-4^{\circ} \mathrm{C}$. The Australian $E$. tereticornis provenances have also been reported to perform better in lateritic soils at Midnapore by BANERJEE et al. (1990).

At FRI campus, the height showed a linear trend with increase in latitude of seed origin. This means the height depicted an increasing pattern while going from north to south Australia. The correlations drawn for the trial at FRI campus are interesting and may be observed for some more years if they persist at later stage of development. Though the height is increasing while moving towards south, but the best perform- ing provenances are from north Queensland. The correlations of height and collar diameter with the latitude were found negative at Midnapore. The negative correlation at Midnapore is in support of previous findings that the north Australian provenances are better performers than the southern ones (ELDRIDGE et al., 1994). The increasing trend of one of the growth trait i.e. survival with decreasing latitude has been reported earlier by Chamshama et al. (1999).

Rainfall and temperature gradient are postulated to play an important role in the formation of clinal variation pattern in growth characters (IsIK, 1986). Similar adaptation strategies along latitudinal gradient have been reported for several forest tree species (REHFELDT, 1983; and HAMRICK and LIBBY, 1972). The patterns of variation (based on coefficient of variation) exhibited for various characters were substantially different and varied differently at various sites. The presence of such difference among populations has probably been produced by different intensities of natural selection acting upon these traits in their natural habitat. Some of the variation found, may be associated with the relatively small number of trees from which seed was collected from each provenance/site.

The local seed source in the present study ranked to be low in comparison to others, which is an indication that there is a better scope of selection of outstanding genotypes from the material under study and introduction of superior provenance for plantations for the enhancement of productivity. The decision on tree breeding strategy is largely dependent upon the extent of variability in the base population which is measured by different population parameters including genotypic and phenotypic variances, and genotypic and phenotypic co-efficient of variation (Subramanian et al., 1995). The genotypic coefficients of variation were comparatively lower than phenotypic coefficient of variation for all the traits. This has also been reported by SubRAMANIAN et al. (1995) for height, girth and clear bole length. The estimates of narrow sense heritabilities for growth traits indicate that a considerable portion of variance is additive. High additive genetic variance and large variation with seed sources offer good scope of genetic improvement of E. tereticornis. In the present study heritability estimates for individual sites are comparable with the findings of PiNOPUSARERK et al. (1996) for E. Camaldulensis which were in the range of 0.07 to 0.20 for height. Lower heritability for stem diameter has previously been confirmed by PURNELL (1986). 
The poor values of the heritability of the trial in Chiryanpur could be due to the heavy weed growth and competition being faced by the experimental plants, as the site is average with respect to maintenance operations and biotic disturbances. The heritability values could be low due to the influence of environmental factors like weed competition and soil parameters on genotypes at each sites. Low heritability values at poor sites have previously been confirmed by PINOPUSARERK et al. (1996).

The phenotypic correlations among height, clear stem height and collar diameter showed highly significant values. It is interesting to note that none of the character had shown negative correlation with each other, thus suggested that these characters may be used to the advantage of the breeder for bringing improvement in these traits simultaneously.

The interaction between the genotype and site can lead to the selection of most productive genotypes (may be provenance/ family) for planting at specific site because the most productive ones at one site may not be the most productive at another site. Existence of provenance $x$ site interaction was evident in the present study. Over all, growth of plants was better at Midnapore. The presence of provenance $\mathrm{x}$ site interaction for height indicates the need for ideotyping site-specific genotypes for maximizing gains (HEGDE, 2002). Existence of provenance $x$ site interaction in E. tereticornis, has earlier been reported by MATHESON and MULLIN (1987) and in nine-month-old seedlings by SiDHU and SINGH (2002).

Variation in provenances of Eucalyptus tereticornis with respect to growth performance is mainly due to the fact that this species grows over a wide range of rainfall, temperature and soil types in Australia and Papua New Guinea. Populations might have experienced marked differences in selective pressure. From the present investigation it is quite apparent that the north Queensland provenances in particular Walsh River, QLD and Burdekin River, QLD are good and stable in their performance in different environmental conditions. North Queensland provenances of E. tereticornis have earlier been reported to perform better in two trials in India by CHATURVEDI et al. (1989). Though present results indicate early performance of the trial, nevertheless are very much informative as far the variability pattern in the test material with regard to growth performance of the provenances is concerned and are also in support of the previous findings (ELDRIDGE et al., 1994).

\section{Acknowledgement}

The authors are grateful to the authorities of CSIRO, Canberra, Australia for providing seed lots of Eucalyptus tereticornis for conducting the experiments.

\section{References}

Banerjee, S. K., Nath, S. and Nandi, Aparjita (1990): Provenance trials of Eucalyptus tereticornis in two lateritic soils of West Bengal. Indian Journal of Forestry 13 (1): 1-7.

Chamshama, S. A. O., Mugasha, A. G. and Wate, P. A. (1999): Variation in performance of Eucalyptus tereticornis provenances at Michafutene, Mozambique. Silvae Genetica 48: 6 .

Chapola, G. B. and Ngulube, M. R. (1991): Productivity and wood properties of some Eucalypts at kasungu flue cured tobacco authority, Malawi. Forest Research Institute of Malawi, Report No. 91008, 29 pp.

Chaturvedi, A. N., Sivaji, P. and Jayram Prasad, D. V. (1989): Eucalyptus provenance trials in Andhra Pradesh. Indian Forester 115: 445-454.

ChATURVEdi, A. N. (1976): Eucalyptus in India. Indian Forester 102: 57-63.
DAVIDSon, J. and DAS, S. (eds.). (1985): Eucalyptus in Bangladesh. Silviculture Division Bulletin No. 6. Bangaledsh Forest Research Institute, Chittagong.

Eldridge, K., Davidson, J., HaRWood, C. and WyK, G. (1994): Eucalypt Domestication and Breeding. Clarendon press. Oxford. Pp. 228-229.

Evans, J. (1992): Plantation forestry in the tropics. Oxford Science Publications. $2^{\text {nd }}$ Edition. 403 pp.

HAMRICK, J. L. and LiBBY, W. J. (1972): Variation and selection in western U. S. Montane species. I. White fir. Silvae Genetica 21 (1-2): 29-35.

HEGDE, R. (2002): Genetic analysis of growth and wood traits of provenances and one-parent families of $E$. camaldulensis Dehnh. Ph. D. thesis, Forest Research Institute (Deemed University), Dehradun, India.

JACOBS, M. R. (1981): Eucalypts for planting. FAO Forestry Series No. 11. FAO, Rome.

KAARAKKA, V. and JohAnsson, S. G. (1993): Early development of Eucalyptus tereticornis provenances exposed to irrigation. Afric. Agric. For. J. 58: 43-47.

LAMPRECHT, H. (1989): Silviculture in the tropics. GTZ. Eschborn, Germany. 296 pp.

MARTIN, B. (1978): L'Eucalyptus comme exotique: recents rogres dans le choix des especes et des provenances. In: Documents FAO third world consultation on forest tree breeding Vol. 1, pp. 155-172. CSIRO, Canberra.

Matheson, A. C. and Mullin, L. J. (1987): Variation among neighbouring and distant provenances of Eucalyptus grandis and E. tereticornis in Zimbabwean field trials. Australian Forest Research 17: 233-250.

OtEGBeYe, G. O. (1985): Productivity in Eucalyptus camaldulensis Dehnh. and its conservation to genetic improvement in the savanna region of Nigeria. Silvae Genetica 34: 121-126.

Pinopusarerk, K., Doran, J. C., Williams, E. R. and WASUAWANICH, P. (1996): Variation in growth of Eucalyptus camaldulensis provenances in Thailand. Forest Ecology and Management 87: 63-73.

PRYOR, L. D. (1966): A report on past performance and some current aspects of the cultivation of quick-growing species (mainly Eucalyptus) in India. Indian Forester 92: 615-622.

PURNELL, R. C. (1986): Early results from provenance/progeny trials of Eucalyptus nitens in South Africa. Proc. IUFRO conference on Breeding Theory, Progeny testing and Seed Orchards, pp. 500-513. Williamsburg, Virginia, USA.

REHFELDT, G. E. (1983): Adaptation of Pinus contorota populations to heterogeneous environments in northern Idaho. Can. J. For. Res. 13 (3): 405-411.

SiDHU, D. S. and SiNGH, B. (2002): Genetic evaluation of indigenous and exotic seed sources of Eucalyptus tereticornis in nursery and under different agro-climatic zones of Punjab early results. In: Recent Eucalypt Research in India ed. By BAGCHI, S. K., VARGESE, M. and SidDAPPA). Institute of Forest Genetics and Tree breeding, Coimbatore, P. 47-56.

Subramanian, K. N., Mandal, A. K. and Nicodemus, A. (1995): Genetic variability and character association in Eucalyptus grandis. Annals of Forestry 3 (2): 134-137.

Timoni, J. L., Coelha, L. C. C., Kageyama, P. Y. and Da Silva, A. A.: Teste de procedencia de Eucalyptus spp. Na regiao de Moji-Guacu (SP). Silvicultura, Sao Paulo 31, 505-507.

Williams, E. R., Matheson, A. C. and Harwood, C. E. (2002): Experimental design and analysis for tree improvement (IInd edition). CSIRO Publishing, Canberra, Pp. 91-117.

ZHOU, W. L. and BAI, J. Y. (1989): Tropical Ecualypt trials on Hainan island, People's Republic of China. In: Trees for the tropics (ed. D. J. BolAND) pp. 79-87. Australian Centre for International Agricultural Research, Canberra.

Zobel, B. J., VAN Wyк, G. and Stahi, P. (1987): Growing exotic forests. A Wiley Interscience Publication. John Wiley and Sons, NY, USA. 508 pp. 